\title{
Long-term effects of remote ischaemic preconditioning in high risk patients undergoing cardiac surgery: follow-up of a randomised clinical trial
}

\author{
A Zarbock ${ }^{1 *}$, J Kellum ${ }^{2}$, H Van Aken ${ }^{1}$, C Schmidt ${ }^{1}$, S Martens ${ }^{1}$, D Görlich ${ }^{1}$, M Meersch ${ }^{1}$ \\ From ESICM LIVES 2015 \\ Berlin, Germany. 3-7 October 2015
}

\section{Introduction}

Acute kidney injury (AKI) is a common complication after cardiac surgical procedures and is associated with an increased morbidity and mortality.

\section{Objective}

In a multicenter randomized trial, we found that remote ischemic preconditioning (RIPC) reduced acute kidney injury (AKI) in high risk patients undergoing cardiac surgery. We now report on the effects of RIPC on longterm outcomes.

\section{Methods}

In this follow up of the RenalRIPC trial, we examined the effect of RIPC the composite end-point of all-cause mortality, need for renal replacement therapy, and persistent renal dysfunction at 90 days $\left(\mathrm{MAKE}_{90}\right)$. Secondary outcomes were renal recovery and dialysis dependence in patients with AKI.

\section{Results}

RIPC significantly reduced the occurrence of MAKE $_{90}$ $(17 / 120(14.2 \%))$ compared to the sham group (30/120 (25.0\%); ARR, 10.8\%, 95\% CI 0.9\%-20.8\%, P = 0.034). In the $108 / 240$ patients who developed post-surgery AKI (RIPC 45 (37.5\%), Sham-RIPC 63 (52.5\%)), 2 (5.3\%) in the RIPC group and $11(22.0 \%)$ in the Sham-RIPC did not recovery renal function by 90 -days; ARR 16.7\%, 95\% $\mathrm{CI}, 3.2 \%-30.2 \%, \mathrm{P}=0.028)$ and $1(2.4 \%)$ versus $8(15.4 \%)$ were dialysis dependent; ARR 13.0\%, 95\% CI, 2.1\%-23.8\%,

${ }^{1}$ University Hospital Münster, Münster, Germany

Full list of author information is available at the end of the article
$\mathrm{P}=0.036)$. A receiver operating characteristic (ROC) curve analysis for the $\mathrm{MAKE}_{90}$ showed best performance for insulin-like growth factor-binding protein 7 (IGFBP7) and tissue inhibitor of metalloproteinases-2 (TIMP-2) ([TIMP-2].[IGFBP7]) at $4 \mathrm{~h}$ (AUC 0.64; 95\% CI 0.547$0.736, \mathrm{P}=0.004)$. The ROC analyses including AKI positive patients showed that [TIMP-2].[IGFBP7] was predictive at $4 \mathrm{~h}$ for renal non-recovery (AUC 0.70; 95\% CI, 0.587-0.818; $\mathrm{P}=0.021$ ) and at $12 \mathrm{~h}$ (AUC 0.74; 95\% $\mathrm{CI}, 0.604-0.879 ; \mathrm{P}=0.006$ ) after cardiopulmonary bypass. The maximum urinary [TIMP-2].[IGFBP7] demonstrated an AUC of 0.75 (95\% CI, 0.640-0.865; P = 0.004). Optimal cut points were determined from the ROC analyses maximizing the Youden Index ([TIMP2].[IGFBP7] at $4 \mathrm{~h}=0.7$; [TIMP-2].[IGFBP7] at $12 \mathrm{~h}=$ 0.67, [TIMP-2].[IGFBP7] maximum $=0.86$ ). Sensitivities ranged from 0.50 to 0.55 , specificities from 0.75 to 0.82 .

\section{Conclusions}

RIPC significantly reduced the 3-month incidence of a composite end point of all-cause mortality, need for renal replacement therapy, and persistent renal dysfunction in high risk patients undergoing cardiac surgery. Furthermore, RIPC enhanced renal recovery in patients with AKI.

\section{Trial Registration}

The trial is registered at http://www.drks.de (Identifier: DRKS00005333).

\footnotetext{
Authors' details

${ }^{1}$ University Hospital Münster, Münster, Germany. ${ }^{2}$ University of Pittsburgh, Pittsburgh, PA, USA.
}

(c) 2015 Zarbock et al.; This is an Open Access article distributed under the terms of the Creative Commons Attribution License (http:// creativecommons.org/licenses/by/4.0), which permits unrestricted use, distribution, and reproduction in any medium, provided the original work is properly cited. 
doi:10.1186/2197-425X-3-S1-A411

Cite this article as: Zarbock et al:: Long-term effects of remote

ischaemic preconditioning in high risk patients undergoing cardiac

surgery: follow-up of a randomised clinical trial. Intensive Care Medicine

Experimental 2015 3(Suppl 1):A411.

\section{Submit your manuscript to a SpringerOpen ${ }^{\mathcal{D}}$} journal and benefit from:

- Convenient online submission

- Rigorous peer review

- Immediate publication on acceptance

- Open access: articles freely available online

- High visibility within the field

- Retaining the copyright to your article

Submit your next manuscript at $\gg$ springeropen.com 